\title{
Postharvest Storage Techniques for Cassava Roots in Ghana- A Review
}

\author{
Evans Ntim Amedor, *, John Yao Afetsu ${ }^{2}$, Robert Akayim Awasina ${ }^{3}$, Wisdom Korang Obeng ${ }^{4}$, \\ Maurice Tibiru Apaliya ${ }^{5}$ \\ ${ }^{1}$ Department of Science, Bia Lamplighter College of Education, Sefwi Debiso, Ghana \\ ${ }^{2}$ Department of Science, St. Teresa's College of Education, Hohoe, Ghana \\ ${ }^{3}$ Department of Science, Gambaga College of Education, Gambaga, Ghana \\ ${ }^{4}$ Department of Science, Berekum College of Education, Berekum, Ghana \\ ${ }^{5}$ Department of Agriculture for Social Change Regentropfen College of Applied Sciences, PMB Bongo, Ghana
}

Email address:

evans.amedor.stu@uenr.edu.gh (E. N. Amedor)

${ }^{*}$ Corresponding author

\section{To cite this article:}

Evans Ntim Amedor, John Yao Afetsu, Robert Akayim Awasina, Wisdom Korang Obeng, Maurice Tibiru Apaliya. Postharvest Storage Techniques for Cassava Roots in Ghana- A Review. International Journal of Applied Agricultural Sciences. Vol. 6, No. 4, 2020 , pp. 80-83. doi: $10.11648 /$ j.ijaas.20200604.15

Received: July 20, 2020; Accepted: July 30, 2020; Published: August 10, 2020

\begin{abstract}
Cassava (Manihot esculenta Crantz.) a staple food assumes a significant role in solving food security issues in Africa. The various uses of the root include the production of starch, cassava chips, gari, flour, and ethanol. A few days after harvest, the roots begin to decay as a result of wounds or microbial contaminations. Because of the high perishability nature of the crop, a few techniques have been employed over the ages to prolong the crop shelf life. This paper surveys the postharvest storage of fresh cassava roots by delving into techniques such as In-field storage, Heap storage, Clamp storage, and Box storage. In present-day time peeled cassava can likewise be cold stored in a deep freezer. The in-field storage technique stores the root for an extra one year yet anyway diminishes the profitability of the land as it cannot be utilized for new harvests. Heap storage under shade trees normally balances the temperature happening during the day and along these lines shielding the tubers from overheating. Notwithstanding, stacking of the produce brings about poor ventilation thereby resulting in a fast spread of decays among the roots. For effective clamp storage, thicker soil cover might be utilized to decrease the temperature in the clamp during hot - dry conditions while care ought to be taken from keeping the roots from getting wet inside the clamp during the wet seasons. For successful box storage, the packing material ought to be moist to maintain high humidity yet not wet as this could produce microbial and mold development.
\end{abstract}

Keywords: Postharvest, Techniques, Storage, Cassava, Shelflife

\section{Introduction}

The storage of agricultural raw materials is a fundamental part of food processing that guarantees that food remains accessible even in times of scarcity. Root and tuber crops are still living organisms after they have been harvested and losses that happen during storage emerge for the most part from their physical and physiological conditions [20]. Cassava (Manihot esculenta) as a root crop is a perennial woody shrub with an edible root, which is developed limitlessly in the tropical regions of the world.
[10] reported that cassava supplies $38.6 \%$ of Africa's vitality caloric prerequisites. In 2013, out of 277 million tons of cassava produced around the world, 158 million tons was from Africa [3]. Cassava assumes a tremendous role in solving hunger and food security issues in Africa in this time of climate change [9]. Cassava can be utilized as raw material for the production of industrial starch, gari, dough, and ethanol. Postharvest losses in cassava vary considerably between zones of production, cultivars, and 
storage conditions. Cassava roots rot within 2-3 days after being unearthed as the produce is of very high moisture content [11]. A recent survey of farmers in Ghana detailed cassava takes an average of 3 days for the roots to decay after harvest [16]. The rapid deterioration consequentially affects marketing and eating quality. Changes in cassava during deterioration include increase sweetness, softening of the root core, browning, and senescence. Several storage techniques have throughout the years been utilized by the crop producers and marketers to prolong /extend the crop's shelf life after harvest. Storing roots at $10^{\circ} \mathrm{C}$ and $80 \% \mathrm{RH}$ can delay the beginning of decay by 14 days $[5,11,6]$, revealed the roots of cassava can be stored at $0-5^{\circ} \mathrm{C}$ and $85-$ $90 \%$ RH for 1-2 months with minimal symptoms even though the crop is chilling sensitive. The goal of this paper is therefore to review the basic postharvest techniques utilized for storing cassava roots in Ghana.

\section{Techniques of Cassava Roots Storage}

The commonly used simple techniques utilized by farmers in storing cassava include In-field storage, Heap method, and Field clamp method and Storage in boxes. The techniques just attempt to limit moisture loss from the tubers thereby prolonging or extending the storage life of the crop.

\subsection{In-Field Storage}

The rapid deterioration of cassava roots after harvest has led farmers to leave the roots in the ground until they are required. That is the unharvested roots are left in the soil after the time of ideal root development and are harvested as and when they are required for utilization processing and marketing. The technique does not provide any form of expenses for erecting any structure. In-field storage has been shown to lessen postharvest losses [18]. More recently, [13] reported that $72 \%$ of cassava farmers in Rwanda delay cassava harvesting for over one year. Although the practice increases the size of the roots to some extent and also stores the root for an additional one or more years, the practice is without disadvantages. The technique decreases the efficiency of the land as it can't be utilized for the cultivation of new roots. [14] report that greater losses occur when roots are left unharvested in-ground during the dry season when the ground becomes dry and hard. According to [19, 17], Cassava roots become easily susceptible to attacks by pathogens and also decrease in starch content when left unharvested in the ground. because old roots occupy the land. In-field storage renders roots to become more woody and fibrous resulting in lower nutritional constituents as a result of high extreme temperatures, attacks by rodents, insects, and nematodes. Fresh roots harvested from in-field rots within 24 to 48 hours and must be immediately used for its purposes.

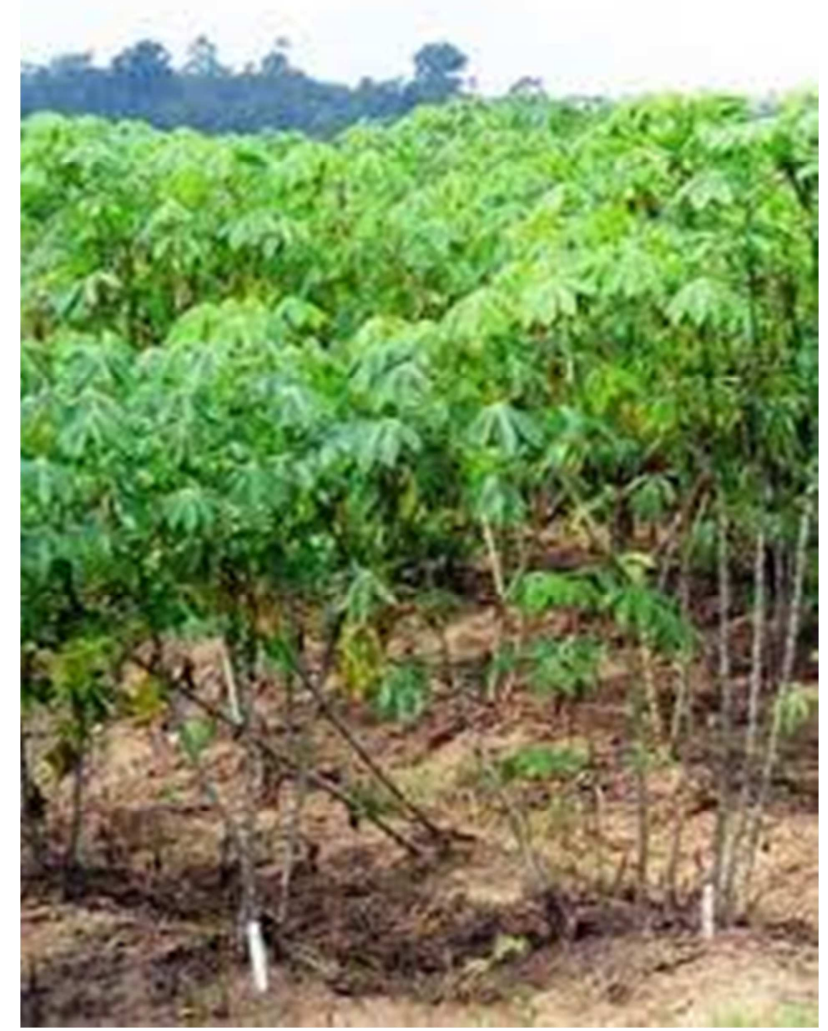

Figure 1. In-field storage.

\subsection{Heap Storage}

The technique includes stacking or mounding the roots, covering them with a thick layer cut grass or straw for insulation, and afterward putting sacks, jute bags, or canvas tarpaulins over the mounds. The practice normally takes place under a tree providing shade and the heap is covered with either maize or millet stalks or other similar materials [8]. This creates warm and humid conditions. Plastic covers are not normally used as the mound can easily become excessively hot and damage the root crop. The technique can be raised at no cost. The shade tree normally balances the temperature occurring during the day and thereby protecting the tubers from overheating. This storage system is ineffectively ventilated as the produce is stacked and this results in the rapid spread of decays among the produce which reduces storage duration. The stored produce is likewise harmed by insects and rodents such as mites and rats which can hide very well in the loaded produce [14]. The storage technique can be improved by the provision of ventilation openings in the store to encourage airflow in the stacked or loaded produce. Injured and microbial infested produce ought not to be stored as these encourage rapid rots and weakening of roots. Again materials to be utilized as cover ought to be checked for traces of urine and faeces as the presence of these harbours microbes which cause spoilage of the roots. 


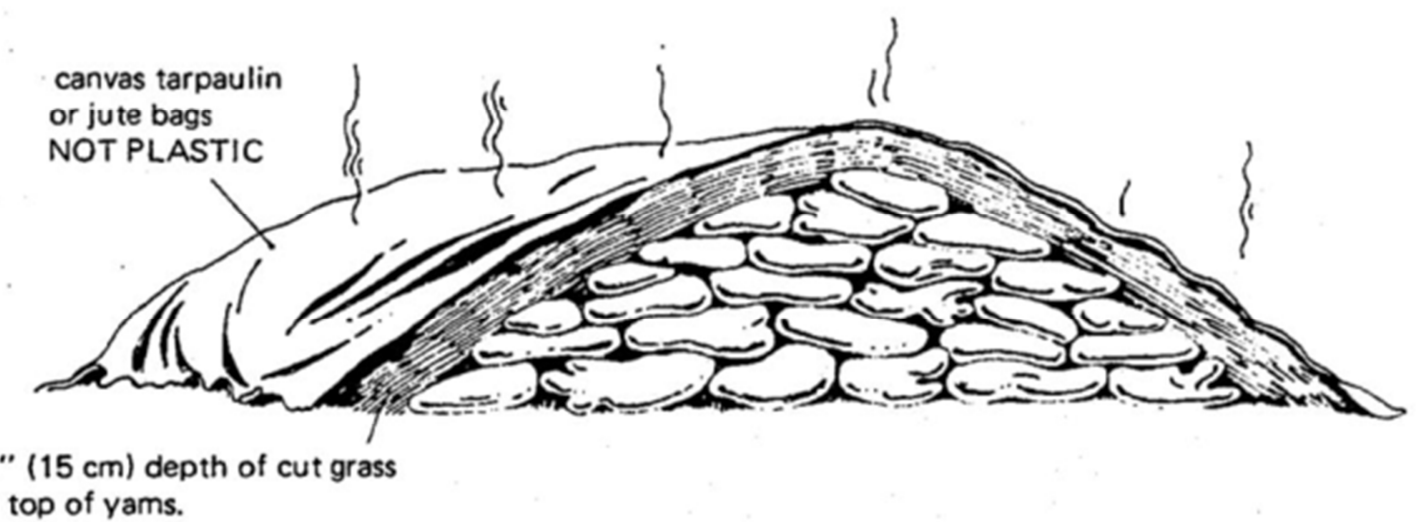

At least 6" $(15 \mathrm{~cm})$ depth
placed on top of yams.

Figure 2. Heap storage.

\subsection{Field Clamp Storage}

The storage technique is comparable in design to European potato clamps researched at the Centro Internacional de Agricultura Tropical Colombia (CIAT), Cali, Colombia, [7, 4]. The technique has been found out to cure and store cassava roots effectively for periods of three to 11 months, depending on the type of clamp design and the prevailing temperature of the immediate surroundings [5]. The clamp is built on well-drained soil, by first making a round bed of rice straw of $1.5 \mathrm{~m}$ in diameter and of adequate thickness so that when compacted it was around $150 \mathrm{~mm}$ thick. Roots of about 500 are then stacked on the straw in a conical manner. Roots used are unselected to achieve variation in sizes and also to have a substantial proportion with mechanical damage. Unselected roots are used so that there is a large variation in root size and a substantial proportion of roots with mechanical damage. The heap is then covered with straw which compacted to a layer of $150 \mathrm{~mm}$ thick. The whole clamp is then covered with a soil of thickness of 100-150 mm. For effective clamp storage during hot, dry conditions, it is important to ensure that the internal temperature in the clamp does not exceed $40^{\circ} \mathrm{C}$. [5], revealed the use of clamp technology in different seasons at CIAT resulted in effective recoveries of $75 \%$ of the initial weight (or 85 to $90 \%$ of the final weight) of roots in marketable quality conditions after 1 month of storage. Second and third, months of storage resulted in very minimal losses. The high losses in the roots occurred during periods when temperatures rose above $400^{\circ} \mathrm{C}$ in the clamp and also during the wet seasons when rainfall had entered the clamp. [1], revealed that during cool temperatures of frequent but light rainfall, severely damaged roots have been effectively cured and stored with acceptable levels of $0-20 \%$ for up to 2 months whereas roots with minimal rots were stored for up to 3-6months. However, heavy losses resulted even after 1 month of storage when rains entered the clamp during the dry season. It can be concluded from the investigations that stored roots are cured and this can be seen as there is a wound healing on the root after I month of storage using the technique.

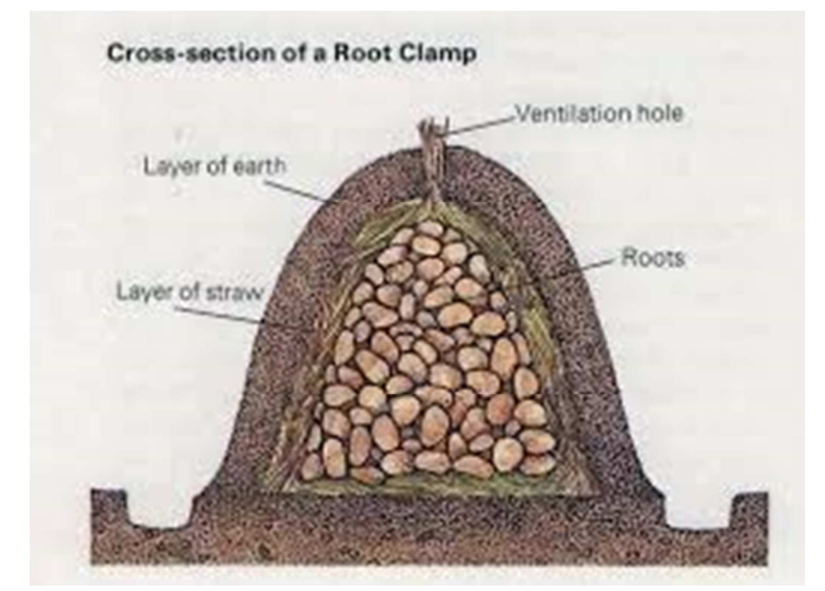

Figure 3. Field clamp storage.

\subsection{Storage in Boxes Lined with Moist Sawdust or Wood Shavings}

The technique involves putting an alternate layer of sawdust or other packing materials and cassava roots in a box for storage. For effective storage, the packing material ought to be moist to maintain high humidity but not wet as this could encourage microbial and mold activities. again roots to be stored should have no or little damage to prolong shelf life. Once packed the boxes can be stored in the shade under a tree or thatched roof or waterproof tarpaulin. According to [2] box storage of cassava roots in moist sawdust at room temperature at CIAT was unsuccessful in controlling cassava streak diseases but rather led to severe rots whereas the technique was successful in storing the roots at ambient conditions. According to [12] investigations into box storage in Uganda revealed $75 \%$ of roots stored immediately after harvest remained acceptable after 4 weeks of storage but with a delay of one day $50 \%$ of roots were rated ads unacceptable. [15] detailed that the technique has been effectively employed in the export markets but the higher transportation costs limit its use in the local markets. Where a crop is grown distance away from market outlets the technique provides a simple handling and transportation aid to the smallholder farmers. 


\subsection{Alternative Method of Storing Cassava}

According to [21] fresh cassava buried in the soil covered with moist soil can store for over two weeks. It can be peeled and cut into pieces and then dried before storing (Kokonte). The peeled cassava can also be cold stored in a deep freezer. Again fresh cassava is stored by putting into containers and covered with water.

\section{Conclusion}

This review has explored the techniques for storing cassava roots by smallholder farmers in Ghana. Storage techniques such as in-filed storage heap storage field clamp and box storage are common practices employed by smallholder farmers in prolonging the storage life of the root crop. Adhering to these techniques will go a long way to reduce losses in the crop thereby improving farmers' income. Locally available materials can be used in raising the storage structures making it cost-effective and easy to apply in the field.

\section{Competing Interests}

All the authors do not have any possible conflicts of interest.

\section{References}

[1] Araulla E. V., Barry N., \& Marilyn C. (1974). Cassava Processing and Storage. Proceedings of an Interdisciplinary Workshop, Pattaya, Thailand.

[2] Averre, C. W. (1967). Vascular streaking of cassava roots. In International Symposium on Tropical Root and Tuber Crops, Trinidad. Proceedings. 2 (4): 31·35.

[3] Bennett B. (2015). Guest editorial: Smallholder cassava production and the cassava processing sector in Africa. Food Chain 5, 1-3.

[4] Booth, R. H. (1973). Control of deterioration of tropical root crops. Proc. 2nd Int. Congr. PIt Path. In press).

[5] Booth, R. H. (1976). Storage of fresh cassava (Manihot esculenta). 1. Postharvest deterioration and its control. Experimental Agriculture 12, 103-111. Cited by Ravi et al., 1996.

[6] Cantwell, M. (2002). Appendix: Summary table of optimal handling conditions for fresh produce. In: Kader (Ed). Postharvest technology of horticultural crops. University of California, ANR. Publication 3311.

[7] CIAT. (1972). Cassava production systems: fresh root storage. Centro Internacional de Agricultura Tropical Annu. Rep. 1972. p. $74-78$.

[8] Food and Agriculture Organization (FAO) (1990). Prograrnme d'action pour la prntion des pertes de produits alimentaires, rapport d'activitsur l'amoration du stockage des ignames en milieu paysan, Lom.
[9] Gizachew K. B., Eyasu E., Pheneas N., Gudeta W. S. (2018). Cassava response to the integrated use of manure and NPK fertilizer in Zambia. Heliyon 4 (2018) e00759.

[10] MoFA (2009). Facts and Figure, Agriculture in Ghana, Ministry of Food and Agriculture, Accra, Ghana.

[11] Morante, N., Sanchez, T., Ceballos, H., Calle, F., Perez, J. C., Egesi, C., Cuambe, C. E., Escobar, A. F., Ortiz, D., Chavez, A. L., \& Fregene, M. (2010). Tolerance to postharvest physiological deterioration in cassava roots. Crop Science 50, 1333-1338.

[12] Nahdy, S. M. and Odong, M., (1995). Storage of fresh cassava tuber in plant based storage media. In: Proceeding of the Workshop on "Postharvest Technology Experience in Africa", Accra, 4-8 July 1994. Edited by FAO, Rome.

[13] Nduwumuremyi, A., Melis, R., Shanahan, P., \& Asiimwe, T. (2016). Participatory appraisal of preferred traits, production constraints and postharvest challenges for cassava farmers in Rwanda. Food Security 8, 375-388.

[14] Nwankiti, A. D. O. et al. (1989). Traditional and Some Improved Storage Methods for Root and Tuber Crops in Nigeria in: DEUTSCHE STIFTUNG F INTERNATIONALE ENTWICKLUNG (DSE) (edi.): Roots, Tubers and Legumes, Bonn, pp 51-67.

[15] Osunde Z. D., \& Fadeyibi A. (2011). Storage methods and some uses of cassava in Nigeria. Continental J. Agric. Sci. 5 (2): 12-18.

[16] Prempeh R., Manu-Aduening, J. A., Asante, B. O., Asante, I. K., Offei, S. K. \& Danquah, E. Y. (2017). Farmers' knowledge and perception of postharvest physiological deterioration in cassava storage roots in Ghana. Agriculture \& Food Security 6, 27.

https://agricultureandfoodsecurity.biomedcentral.com/articles/ 10.1186/s40066-017-0103-y.

[17] Ravi V, Aked J., \& Balagopalan C. (1996). Review on tropical root and tuber crops I. Storage methods and quality changes. Critical Rev. Food Sci. Nutr. 36: 661-709.

[18] Stathers, T., Bechoff, A., Sindi, K., Low, J., Ndyetabula, D. (2013). Everything You Ever Wanted to Know about Sweetpotato: Reaching Agents of Change ToT Manual. 5: Harvesting and postharvest management, Processing and utilisation, Marketing and entrepreneurship. International Potato Center, Nairobi, Kenya. vol. 5.

[19] Osunde Z. D and Fadeyibi A. (2011). Storage method and some uses of cassava in Nigeria [online]. Available from: https://www.researchgate.net/publication/261378860 STORA GE_METHODS_AND_SOME_USES_OF_CASSAVA_IN_N IGERIA (15-01-2020) [Accessed 22 January, 2020].

[20] Sasu G. M, Kwateng E. N, Baffou-Antwi A. K (2013). General Agriculture for Senior High Schools. Adwinsa Publicaions (GH) Ltd. Legon -Accra.

[21] Wenham J. E. (1995). Post-harvest deterioration of cassava. A biotechnology perspective. FAO Plant Production and Protection Paper 130. NRI/FAO. Rome. P. 90. 